\title{
Introduction to the dossier
}

\author{
Maria Laura Viveiros de Castro Cavalcanti \\ Programa de Pós-graduação em Sociologia e Antropologia, Instituto de Filosofia e Ciências Sociais, \\ Universidade Federal do Rio de Janeiro, Rio de Janeiro/RJ, Brasil
}

\author{
Renata de Sá Gonçalves \\ Departamento de Antropologia, Programa de Pós-graduação em Antropologia, \\ Universidade Federal Fluminense, Niterói/RJ, Brazil
}

In talking about ritual, we apprehend the symbolic nature of human action with its multiple possibilities for expression. In talking about performance, we emphasize this action as an exercise in (re) enactment. The two notions complement each other and sometimes overlap in the different currents of the anthropological tradition and likewise in this dossier.

Since modern anthropology's origins at the end of the nineteenth century, the notion of ritual has enabled the concrete and lived dimension of human experience to be inextricably articulated with forms of symbolization that extend far beyond the spoken word. Émile Durkheim's The Elementary Forms of the Religious Life (1912), in particular, renewed the analysis of rituals with an emphasis on the symbolism, creativity and potency of human action, explored in the remarkable Chapter VII of Book II. He also indelibly associated the notion of ritual with the continual production and reproduction of the social bond. A little earlier, Arnold Van Gennep's conceptualization of rites of passage had shown the universality of ritualization in the successive changes and transformations through which individuals and groups pass through the course of their social existence (Van Gennep 1909). In the context of the renowned works of the French Sociological School, Durkheim postulated the existence of some kind of consistency between ritual practices and symbolic representations, while emphasizing how ritual practices demarcated an extraordinary temporality distinct from day-to-day time. As a scholar of European folklore, Van Gennep apprehended the importance of ritual sequences, the organic progression of their successive stages, and shed light on the significance of threshholds and the experience of liminarity, so critical to the passages that irreversibly transform us from birth to death. Since then, in the encounter between these two currents of the anthropological tradition, the connection between socal life and ritual experience became indissoluble and, as an endless range of possibilities opened up, the notion of ritual never ceased to connect valuable ethnographic studies with a remarkable conceptual production. ${ }^{1}$

1 This articulation between the ethnography of rituals and conceptual production makes theories of ritual always theories of culture. The theme pervades a considerable part of the anthropological literature in a prominent form. Among others we can mention Malinowski (1961 [1922]), Radcliffe-Brown (1933 [1922]), Bateson (1933), Gluckman (1962), Douglas (1966), Turner (1967), Leach (1970), Valeri (1970), Geertz (1980), Tambiah (1985),DaMatta (1979) and Peirano (2001). 
The notion of performance, in turn, emerged out of the confluence between the theoretical production in diverse fields of knowledge (such as linguistics, anthropology itself, literature, ethnomusicology and folklore studies ${ }^{2}$ and the multidimensional artistic field. In the arts during the second half of the twentieth century, performance came to valorize the simultaneity of expressive forms and the subjective apprehension of time as the unfolding of a lived experience; the art work made alive through the body of the artist, or even the work as the artist's body itself, and to be lived with the public; the value of the physicality of this mutual presence and the non-verbal or non-discursive forms in the apprehension of the meaning of aesthetic experience; and the search for a more direct relationship with social life (Glusberg 2009). All of this ressonates with themes explored by anthropological studies since Durkheim's precursor Robertson Smith (2005 [1894]), and echoed strongly in the more contemporary anthropology of rituals. In the new era of fluid disciplinary boundaries (Geertz 1983), Victor Turner, with his own intellectual biography, perhaps expresses better than anyone this trajectory taken by the notion of ritual, which moves from the classical anthropology of the 1940s/1950s to the opening up of the discipline to the artistic field in the 1980s, expressed in the increasing valorization of the notion of performance (see Silva 2010, Cavalcanti 2013). It is also worth mentioning the close dialogue between Turner with the anthropology undertaken in Brazil from the 1960 os to the 1980 (Cavalcanti, Sinder \& Lage 2013). ${ }^{3}$ Although the notion of performance contains very diverse theoretical emphases, ${ }^{4}$ Turner's strong presence in the bibliography of the articles in this dossier attests to his enduring and varying influence in the anthropology of rituals and performances.

In the Brazilian literature, a striking interest in the practices later conceptualized as rituals can already be found in the sixteenth-century descriptions of native customs and ways of life made by the early European colonists (see Baldus 1949). In studies of folklore and in community studies - formative currents of the Brazilian social sciences from the beginning of its institutionalization in the country's universities in the 1930s and 1940s - the topic also makes its presence felt in an innovative way (see Pierson 1949). These works, incidentally, have seen a revival in interest, as indicated by the article by Elizabeth Travassos and the essay by Mário de Andrade, “The Music of Sorcery in Brazil," published in the Déjà Lu section of this dossier.

Boosted by state support for postgraduate courses, the 1970s was a period of renewal in Brazil's social sciences. Anthropology enjoyed one of its most productive phases. In this context, the study of ritual acquired considerable prominence, with the production of substantial research being accompanied by the publication of numerous books and translations. It is worth mentioning the works of Azevedo (1975), Melatti (1978), Agostinho (1974), Rodrigues (1979), Maggie (1975) and Prado (2007 [1977]) among others. Hence, by shifting the anthropological perspective to the epicentre of the intellectual scene of the time, attaining a much wide public, Roberto DaMatta's Carnavais, malandros e heróis, published in 1979, can be seen as the culmination of the effervescent interest stirred by ritual. Over this same decade, we can also thank DaMatta for introducing the Portuguese-reading public to classic works from the study of ritual in the 'Coleção Antropologia' series published by Editora Vozes, ${ }^{5}$ including The Ritual Process by

\footnotetext{
2 In linguistic we can highlight Austin (1962) and Searle (1969, 1979); in oral literature, Zumthor (1972); in ethnomusicology, Blacking (1973) and Seeger (1994); in folklore studies, Bauman (1977); and in anthropology itself, Malinowski (1972) and Tambiah (1968; 1973).

3 Here it is worth mentioning Victor Turner's visit to Brazil at the start of the 1980s, recalled by Da Matta (2005). Edith and Victor Turner went with Celeste and Roberto DaMatta to watch the Rio carnival in 1980, which inspired Turner to produce an article on the subject (1987b) in which he engages in a close dialogue with DaMatta (1979). Turner's book The Anthropology of Performance (1987) is a posthumous collection editorial by Richard Schechner and, due to a publishing lapse, the article in question is missing the cited bibliography. On the same visit to Brazil, the Turners also accompanied Yvonne Maggie on a visit to an umbanda center in Rio de Janeiro, which also prompted the author to write an article on social drama and theatricality (Turner $1987 \mathrm{c}$ ) in direct dialogue with Guerra de Orixá: um estudo de ritual e conflito (see the postface to Maggie 2001). On this topic, see Cavalcanti, Sinder \& Lage (op. cit.).

4 For a survey of different theories of drama and performance in the anthropological and artistic field, see Silva (2005). On the performative current in the anthropology of ritual, see Peirano (2002). On the discussion of the notions of drama, ritual and performance in Victor Turner, see Cavalcanti (2013).

5 DaMatta also edited and wrote the foreword to the Edmund Leach volume of the 'Grandes Cientistas Sociais' collection published by Editora Ática in 1983.
} 
Victor Turner (1974) and The Rites of Passage by Arnold Van Gennep (1977). The publication in English for the first time of DaMatta's article "Indivuality and Liminarity: some considerations concerning rites of passage and modernity" in the Déjà Lu section of the dossier provides a clear example of the liveliness and creativity of DaMatta's thought.

Since then, the study of rituals, with the innovations introduced by theories of performance, speech acts, aesthetic agency and things, have traversed boundaries both inside and outside of anthropology, articulating a fruitful dialogue between studies of political anthropology, indigenous ethnology, urban anthropology, and anthropologies of religion, popular culture and gender, among other areas of specialization. Mapping the wealth of research in this field of studies, however, would go far beyond the objectives of this presentation. ${ }^{6}$

In this dossier, works that are today classics, continually relived and re-read by new generations of anthropologists and scholars of culture more generally, appear alongside more contemporary work, providing a small but expressive demonstration of the possibilities open to the field of ritual and performance studies in Brazil.

Located in the tradition of studies of religion and focusing in particular on Catholic processions, Edilson Pereira in "The bodies of Christ: performances and agencies of the Passion in Ouro Preto, Minas Gerais" explores the frontiers between ritual and theatre, on one hand, and religion and art, on the other. He analyses the enactments of the Passion of Christ taking place during the Holy Week celebrations in the city of Ouro Preto, following the actors who perform the main protagonist's role, along with their different forms of rehearsal, in the city's outlying regions. The conceptions of their practices are explored through, and compared with, the idea of a continuum between the domains of ritual and theatre identified by Victor Turner and Richard Schechner. He argues that the semantic scope of their notion of performance remains insufficient to explore ethnographic settings that transcend the actor-audience duality. Through the analysis of the actors playing the role of Christ, he identifies their bodies as the primary locus of action and indicates different agencies in their performances.

Vânia Cardoso, in "Danger of Words: risk and (mis)comprehension in consultations with the spirits of the people of the streets," proposes an approach to Afro-Brazilian religiosity that focuses on oral performances and the productive indeterminacy engendered by them. She argues that the spiritual entities known as 'the people of the streets' can be taken as the very materialization of the principle of indeterminacy, considered at once dangerous and powerful. She turns her attention to the consultation sessions with these entities, foregrounding the encounter between clients and entities as a moment of instability, where the vulnerability of language - the danger of words - is at the centre of ritual efficacy.

Festive expressions also gain a prominent place in ritual studies. Carnival, a festive rite, and the brincadeiras contain cultural expressions as traditional as they are inventive. Defining themselves through specific aesthetic forms, such expressions are constantly arranged, reordered and given new meaning. These moments, each regulated in its own way, at the same time provide space for embellishment, creativity and invention. Taking the ethnography of a Maracatu in Recife, Pernambuco, as her focus, Laure Garrabé, in "La brincadeira, genre métis: performance, dissensus et esthétique décoloniale", reflects on the brincadeira as a genre of performance through an analysis that articulates aisthesis, the decolonial option and the politics of aesthetics, seeking to contribute to the relatively new perspective of decolonial

6 Here we refer the reader to Cavalcanti \& Gonçalves (2010). Also we cannot fail to mention the studies of carnival that preceded and followed in the wake of the approach initiated by Roberto DaMatta, such as Goldwasser (1975), Leopoldi (1978), Cavalcanti (2006 [1994]), Gonçalves (2010), among others. 
aesthetics. The analysis sheds light on the singularities of Maracatu, understood as a logic of dissensus that produces a simultaneously conceptual and vitalist dimension of multiplicity. She considers the performative modalities of the brincadeira as an undisciplined aesthesis and explores its potential contribution to the decolonial aesthetics project.

"Les réseaux que affinent: la conversion symbolique des fromages artisanaux à Minas Gerais" by Leonardo Vilaça Dupin works to establish a stimulating dialogue between the world of microbiology and the world of culture by highlighting the symbolic and ritual dimension of food transformation. The article is devoted to thinking the 'social life' of cheese from Serra da Canastra, in Minas Gerais, by focusing on the process of maturation that transforms 'natural' and thus 'impure' and 'health-threatening' food into a 'pure' and 'healthy' item 'fit' for human consumption. This process of the simultaneously biological and symbolic transformation encompasses a wide network of different actors and moments that make up the 'social life' of the cheese.

In "The Pataxó baptism rite at Aragwaksã," Rodrigo Grünewald reflects on the interactions of indigenous groups in contemporary Brazil through an examination of the baptism rite of the Pataxó Indians living in the Coroa Vermelha Indigenous Land, located in the Porto Seguro region on the southern coast of Bahia. The rite in question incudes the Aragwaksã ceremony, performed periodically in the Jaqueira Ecological Reserve, an area of environmental protection and ethnotourism situated within the indigenous land, created in 1999 by the indigenous people themselves and administrated by them. The article frames the baptism rite conducted during the Aragwaksã ceremony as a performance of the Pataxó Indians undertaken in an inter-cultural arena and highlights the participative and creative interaction of indigenous people and tourists in the execution of the event.

Finally, in “(In)visible Blood: menstrual performances and body art," Daniela Manica and Clarice Rios adopt an original approach to a set of contemporary artistic performances that possess as a common element the use of menstrual blood as a base material and also a vector of senses and experiences. In the article, the term menstrual performance refers to various ways in which menstrual blood is used as an aesthetic and political expression in the eyes of the performers. The authors' argument stresses two aspects of these performances: the emotional resonance of certain physical experiences and bodily substances, such as menstruation and menstrual blood; and the physical devices, such as the menstrual cup and the internet, that allow these performances involving menstrual blood to grow in number and frequency.

The Déjà Lu section opens with the aforementioned article by RobertoDaMatta, "Indivuality and Liminarity: some considerations concerning rites of passage and modernity." The author explores a critical link between the idea of liminarity, engendered by anthropological monographic studies, and the idea of individuality, a key concept within the classical tradition of the socio-historical studies of great civilizations. DaMatta establishes a bridge between these two concepts by focusing on certain underdiscussed aspects of rites of passage. In his view the 'liminal' phase of rites of passage is linked to the ambiguity brought about by the isolation and individualization of the initiate. It is thus the experience of being 'outside-the-world' that brings forth and characterizes liminal states, not the other way around - in short, it is individuality that engenders liminarity. Rites of passage transform this experience into complementarity, into an immersion within a network of social relationships, while ordeals, in contrast, establish a model for the plenitude of social life.

Next comes "A Colloquium of Sorcerers: Mário de Andrade, Fernando Ortiz, and the music of sorcery" by Elizabeth Travassos. She examines the ideas of the Brazilian writer and musicologist Mário de Andrade (1893-1945) and those of the Cuban writer and anthropologist Fernando Ortiz (1881-1969) concerning the relations between music and sorcery in Afro-American conceptions and rituals. Both authors constitute important references in the study of cultures of African origin in their respective countries, and their 
interest in this subject is expressed by their in-field observations, books and articles.

The essay explores common characteristics and contrasts in their approaches to the theme and suggests that the debate should not be limited to the history of ideas, since it echoes contemporary theories of 'speech acts,' performativity, and aesthetic agency.

In "Brazil's music of sorcery according to Mário de Andrade: an introduction by the editors", Maria Laura Cavalcanti and Peter Fry, the editors of this English version of Andrade's essay, introduce the readers to their editorial decisions and to the difficulties and limits of the translation of the author's characteristic, and often idiosyncratic, Brazilian Portuguese. In Andrade's text, erudite analyses intermingle with the famous description of the ceremony of fechar o corpo (closing the body) to which the author asked to be submitted in his field research on the Brazilian Northeastern catimbó. Bringing in the subsequent anthropological literature, Cavalcanti and Fry also discuss Andrade's often critical evaluations of this ceremony. They observe that while this description comprises the high point of the essay's ethnographic analysis, from a musical perspective it is the macumba of 1930 s Rio de Janeiro that occupies the place of honour.

"The music of sorcery in Brazil," originally a lecture given by Mário de Andrade to the Brazilian Music Association (Associação Brasileira de Música) in Rio de Janeiro, in 1933, concludes the dossier. Pursuing an innovative approach, Andrade seeks out the role of music, with its distinctive rhythms and melodic forms, in the mystical trance of Afro-Brazilian religions. The text combines the flavour of his direct research experience in the catimbó of the Brazilian Northeast with his erudite bibliographical studies, strongly influenced by the evolutionary and diffusionist anthropology of the end of the $19^{\text {th }}$ century and beginning of the $2 \mathrm{O}^{\text {th }}$, and an analysis of macumba music in Rio de Janeiro around the 1930s, as found in the recordings that Andrade so much enjoyed collecting and listening to.

Translated by David Rodgers

\section{References}

AGOSTINHO, Pedro. 1974. Kwarip, mito e ritual no Alto Xingu. São Paulo: EDUSP.

AUSTIN, John. 1962. How to do things with words. Cambridge: Harvard University Press.

AZEVEDO, Thales. 1975. Namoro à antiga: tradição e mudança. São Paulo: Editora Ática.

BALDUS, Herbert. 1949. "Etnologia”. In Manual Bibiográfico de Estudos Brasileiros. Rio de Janeiro: Gráfica Editora Souza p. 199-255.

BATESON, Gregory. 1936. Naven: a survey of the problems suggested by a composite Picture of the culture of a New Guinea tribe drawn from three points of view. Cambridge ( Eng.): The University Press.

BAUMAN, Richard. 1977. Verbal art as performance. Prospect Heights, Illinois: Waveland Press.

BLACKING, John. 1973. How musical is man. Seattle: University of Washington Press.

CAVALCANTI, Maria Laura Viveiros de Castro. 2013. "Drama, ritual e performance em Victor Turner”. In Sociologia \& Antropologia. Rio de janeiro, v.03.06, pp. 411-440, novembro. . 2006 [1994] Carnaval carioca: dos bastidores ao desfile. 3 ed ( rev.). Rio de Janeiro: Ed. UFRJ.

CAVALCANTI, Maria Laura Viveiros de Castro e GONÇALVES, José Reginaldo. 2010. "Cultura, festa e patrimônio". In DUARTE, Luiz Fernando Dias (Ed.) Horizontes das Ciências Sociais no Brasil. Antropologia. São Paulo: ANPOCS/ Ed. Carcarolla/ Discurso Editorial. 
CAVALCANTI, Maria Laura Viveiros de Castro; SINDER, Valter e LAGE, Giselle Cantarino. 2013. "Victor Turner e a antropologia no Brasil. Duas visões. Entrevista com Roberto DaMatta e Yvonne Maggie. Sociologia \& Antropologia, v.03.06, pp 339-378. Novembro.

DAMATTA, Roberto. 1979. Carnavais, malandros e heróis: para uma sociologia do dilema brasileiro. Antropologia Social. Rio de Janeiro: Zahar Editores.

. 1991. Carnivals, Rogues, and Heroes: An Interpretation of the Brazilian Dilemma. Notre Dame: University of Notre Dame Press.

. 2005. "Apresentação liminar à obra e à graça de Victor Turner e à sua antropologia da ambiguidade". In Turner, Victor. Floresta dos símbolos: aspectos do ritual Ndembu. Niterói: EdUFF. pp. 15-28.

. 2011 [1977]. “Apresentação”. In: Van Gennep, Arnold. Ritos de Passagem. Petrópolis: Editora Vozes.

pp. 9-20.

. DaMatta, Roberto (org.). 1983. Edmund Leach. Rio de Janeiro: Ática, 1983.

DOUGLAS, Mary. 1966. Purity and danger. London, New York. Routledge.

DURKHEIM, Émile. 1912. Les formes elémentaires de la vie religieuse. Le système totémique en Australie. Paris: $\mathrm{F}$.

Alcan.

GEERTZ, Clifford. 1980. Negara: the theatre state in the nineteenth century Bali. Princeton (NJ): Princeton University Press. . 1983. Local Knowledge. Further essays on interpretive anthropology. New York: Basic Books.

GLUCKMAN, Max (Ed.). 1962. Essays on the ritual of social relations. Manchester: Manchester University Press. GLUSBERG, Jorge. 2009. A arte da performance. São Paulo: Perspectiva. GOLDWASSER, Maria Júlia. 1975. O palácio do samba. Rio de Janeiro: Zahar, 1975. GONÇALVES, Renata. 2010. A dança nobre do carnaval. Rio de Janeiro: Ed. Aeroplano.

LEACH, Edmund. 1970. Political systems of High Burma. London: Athlone Press.

LEOPOLDI, José Sávio. 1978. Escola de samba ritual e sociedade. Rio de Janeiro: Ed. Zahar.

MAGGIE, Yvonne. 1975 Guerra de Orixá. Um estudo de ritual e conflito. Rio de Janeiro: Zahar Editores. . 2001. "Pósfácio". In Guerra de Orixá: um estudo de ritual de conflito. 3. ed. Rio de Janeiro: Jorge Zahar Editor, pp. 157-181 .

MALINOWSKI, Bronislaw. 1961 [1922]. The Argonauts of Western Pacific: an account of native enterprise and adventure in the archipelagoes of Melanesia, New Guinea. New York: E.P. Dutton.

. Malinowski, Bronislaw. 1972. "O problema do significado em linguagens primitivas". In: Ogden,

Charles K. \& Richards, Ivor A. (orgs.) O significado do significado. Rio de Janeiro: Zahar Eds. pp. 295-330.

MELATTI, Júlio Cezar. 1978. Ritos de uma tribo Timbira. São Paulo: Ática.

PRADO, Regina Paula dos Santos. Todo ano tem: as festas na estrutura social camponesa. São Luís: PPGCS/ GERUR/EDUFMA, 2007.

PEIRANO, Marisa. 2001. "A análise antropológica dos rituais". O dito e o feito. Rio de Janeiro: Relume Dumará. pp. 17-40.

PIERSON, Donald. 1949. “Sociologia”. In Manual Bibiográfico de Estudos Brasileiros. Rio de Janeiro: Gráfica Editora Souza. pp. 789-851.

RADCLIFFE-BROWN, Alfred Reginald. 1933 [1922]. The Andaman Islanders. Cambridge (Eng.): The University Press.

RODRIGUES, José Carlos. 1979. Tabu do corpo. Petrópolis: Ed. Vozes.

SEARLE, John R. 1969. Speech acts. An essay in the philosophy of language. Cambridge: Cambridge University Press.

.1979. Expression and meaning: studies in the theory of speech acts. Cambridge (Eng.), New York: Cambridge University Press. 
SEEGER, Anthony. 1994. "Music and dance". In: Ingold, Tim (Ed.). Companion encyclopedia of anthropology. Londres/Nova York: Routledge. pp. 686-705.

SILVA, Rubens Alves. 2005. Entre "artes" e "ciências": as noções de performance e drama no campo das ciências sociais. Horizontes Antropológicos, 11/24, pp. 35-65

SMITH, Robertson. (2005 [1894]). Lectures on the religion of the Semites. Londres: Adamant Media Corporation. (Elibron Classic Series)

TAMBIAH, Stanley. 1985. Culture, thought and social action: an anthropological perspective. Cambridge: Harvard University Press. . 1973. "Form and meaning of magical acts". In: Horton, Robin \& Finnegan, Ruth (Eds.). Modes of thought. Londres: Faber and Faber, p. 199-229. . 1968. "The magical power of words". Man, 3/2, p. 175-208

TURNER, Victor. 1967. The forest of symbols: aspects of Ndembu ritual. Ithaca (NY): Cornell University Press. . 1987a. "The anthropology of performance". In: The Anthropology of performance. New York: PAJ Publitions. Pp. 72-98. . 1987b. "Carnaval in Rio: Dionysian drama in an industrializing society". In The anthropology of performance. New York: PAJ Publications, pp. 123-138. . 1987c. "Social dramas in Brazilian Umbanda: the dialetics of meaning". In: The Anthropology of performance. New York: PAJ Publitions. pp. 33-71.

VALERI, Valerio. 1970. Kinship and sacrifice. Ritual and society in ancient Hawaii. Chicago/London: Chicago University Press.

VAN GENNEP, Arnold. 1909. Les rites de passage. Paris: Éd. Nourry.

ZUMTHOR, Paul. 1972. Essai de poétique médievale. Paris: Éditions du Seuil.

\section{Maria Laura Viveiros de Castro Cavalcanti}

Graduate Program in Sociology and Anthropology, Institute of Philosophy and Social Sciences, Federal University of Rio de Janeiro

E-mail: cavalcanti.laura@gmail.com

\section{Renata de Sá Gonçalves}

Department of Anthropology, Graduate Programme in Anthropology, Fluminense Federal University E-mail: renatagoncalves@id.uff.br 